\title{
Psychological aspects in children and parents of children with chronic kidney disease and their families
}

\author{
Alemsungla Aier, MPhil ${ }^{1}$, Priya Pais, MD², Vijaya Raman, PhD $^{1}$ \\ ${ }^{1}$ Department of Psychiatry, St. John's Medical College, Bangalore, India; ${ }^{2}$ Department of Paediatric Nephrology, St. John's Medical College, Bangalore, India
}

Pediatric chronic kidney disease (CKD) is a chronic illness that affects the overall quality of life of patients during childhood. This article highlights the psychological and social burden of CKD in patients and their families. Patients with CKD and their families require comprehensive treatment for psychosocial problems. Therefore, it is crucial for pediatricians to screen for these issues and refer patients and their families for therapy. Tools that are short, easy to administer, and easy to score, such as the Pediatric Quality of Life Inventory or the Childhood Depression Inventory, can be utilized during routine clinical appointments. Reducing the negative impact of CKD on the family will improve the well-being and coping skills of patients and their families.

Key words: Pediatric chronic kidney disease, Psychosocial issues, Evaluations, Interventions, Family

\footnotetext{
Key message

- Childhood chronic kidney disease (CKD) is complex and requires lifetime medical treatment.

- Children with CKD are at risk for emotional, behavioral, social, and academic difficulties that significantly affect their quality of life.

- Caring for children with CKD is stressful for families.

- These unique challenges are crucial and can negatively impact treatment outcomes.

- Awareness of and addressing these evolving psychosocial issues can foster their developing needs.
}

\section{Introduction}

Chronic illnesses that develop in childhood require longterm treatment affect both the child and the whole family. ${ }^{1,2)}$ A meta-analytic review reported that children with "physical disorders" (including asthma, cardiac disorders, cancer, diabetes, inflammatory bowel disease, juvenile idiopathic arthritis, neurological disorders, and sensory disorders) had a higher risk of developing internalizing (e.g., anxiety, depression, social withdrawal) and externalizing symptoms (e.g., hyperactivity and aggressive behavior) and overall adjustment problems and lower self-concept or self-esteem than healthy children. ${ }^{3)} \mathrm{A}$ review that integrated 569 studies that administered the Child Behavior Checklist, Youth Self Report, and Teacher Report Form for children and adolescents with chronic physical illnesses found higher elevations in internalizing problems (withdrawn, somatic complaints, anxious/depressed), externalizing problems (delinquent and aggressive), and total behavior problems than their healthy peers. ${ }^{4)}$

Pediatric chronic kidney disease (CKD) is defined as a reduced glomerular filtration rate $\left(<60 \mathrm{~mL} / \mathrm{min} / 1.73 \mathrm{~m}^{2}\right)$ for at least 3 months or the presence of structural or functional kidney damage (even if the value is greater than $60 \mathrm{~mL} / \mathrm{min} / 1.73 \mathrm{~m}^{2}$ ). ${ }^{5}$ ) The global prevalence of CKD is difficult to assess, as children are frequently diagnosed late, especially in low-resource areas. The prevalence of CKD is $15-74.7$ cases per one million children.6) However, as CKD is often asymptomatic in the earlier stages, it is often underreported or undiagnosed, suggesting an even higher prevalence in children. ${ }^{7)}$

The etiology of CKD in children varies with age. Congenital anomalies of the kidneys and urinary tract (CAKUT) are observed in younger patients. The common causes of CAKUT causing CKD are renal hypodysplasia, bladder outlet obstruction (posterior urethral valves), and polycystic kidney diseases. In children older than 12 years, primary and secondary glomerular diseases are the leading causes of CKD. ${ }^{6,8)}$ Regardless of etiology, $\mathrm{CKD}$ is associated with progressive loss of kidney function and multiple comorbidities, such as anemia, bone mineral disease, hypertension, cardiovascular disease, and electrolyte/acidbased abnormalities, similar to adult CKD patients. In addition, children experience significant growth failure depending on the age, cause, and onset of CKD. ${ }^{9)}$ Those with abnormal lower urinary tracts also require multiple surgeries and interventions to empty the bladder, such as clear intermittent catheterization.

If $\mathrm{CKD}$ progresses to kidney failure, children require maintenance dialysis until they receive a kidney transplant. Hemo-

\footnotetext{
Corresponding author: Vijaya Raman, PhD. Department of Psychiatry, St. John's Medical College, Sarjapur Road, Bangalore 560034, India 凶Email: vijaya.r@stjohns.in, https://orcid.org/0000-0003-0578-5276

Received: 21 July, 2021, Revised: 13 October, 2021, Accepted: 13 October, 2021

This is an open-access article distributed under the terms of the Creative Commons Attribution Non-Commercial License (http://creativecommons.org/licenses/bync/4.0/) which permits unrestricted non-commercial use, distribution, and reproduction in any medium, provided the original work is properly cited. Copyright (c) 2022 by The Korean Pediatric Society
} 


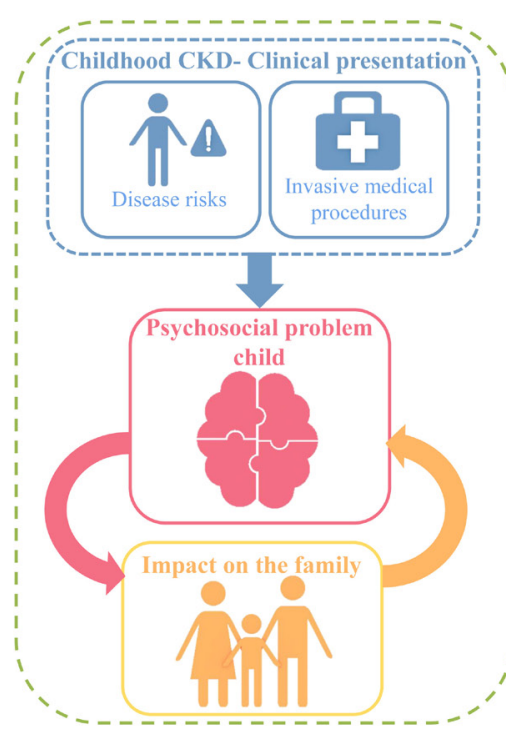

Graphical abstract dialysis is typically performed thrice weekly at a dialysis facility via a catheter or an arteriovenous fistula. Peritoneal dialysis is performed at home daily using an automated cycler machine or manually by a caregiver. Children undergoing dialysis have multiple dietary restrictions.

Given the extent of the comorbidities of pediatric CKD and the challenges of lifelong treatment, the following unique psy. chological and social problems may occur.

\section{Psychological and social problems in children and families with CKD}

With modern medical advances, such as dialysis and kidney transplantation, the survival of children and young people with CKD has noticeably increased. ${ }^{10,11)}$ While long-term survival improves among children with CKD, their overall quality of life remains hampered and often continues in adulthood. ${ }^{12-14)}$ The prolonged need to take medications, frequent contact with medical professionals, and interruptions in schooling and everyday activities may be mechanisms through which the illness increases affected children's psychological problems. ${ }^{15)}$ Caregivers often experience emotional, marital, social, and financial burdens, which may leave families feeling unable to deliver the complex care that children with CKD require. ${ }^{16,17)}$ Moreover, studies of siblings with other chronic conditions revealed that siblings also experience various feelings and reactions, such as sadness, anxiety, stress, or guilt over their good health. ${ }^{18,19)}$ Some of the problems commonly associated with CKD are summarized in Table 1. ${ }^{20-34)}$

Nonetheless, given the condition's effects on this vulnerable patient population's physical and emotional well-being, steps must be taken to provide intensive and ongoing psychological support for children with CKD and their families.

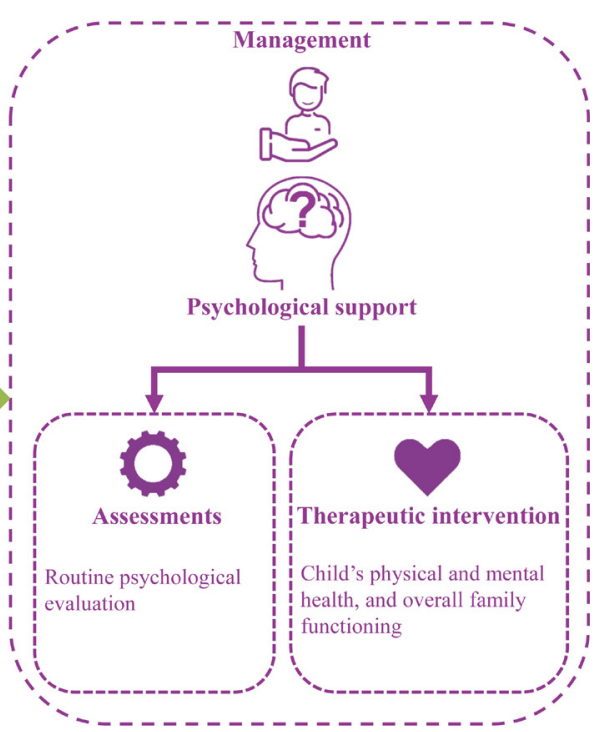

\section{Conceptual framework}

It is essential to understand and examine the various factors that influence the lives of children with chronic illnesses. Theoretical approaches aid in the identification and understanding of the associated psychological risks and guide clinicians in decision-making and planning psychosocial interventions. ${ }^{35)}$ Bronfenbrenner's ecological model has been central in guiding the understanding of risk and resilience as development unfolds and supports a contextualized view of child development and treatment (Fig. 1). ${ }^{36}$ It also provides insight into working with children who have a chronic medical illness and their families and the influence of multiple systems, such as the extended family, school, neighborhood health care system, and community, on the child's interactions and development. This model ensures that a clinician examines the subsystems of the child's world that play prominent roles in their adjustment and outcomes. ${ }^{37)}$

\section{Need for psychosocial evaluation}

Routine psychological evaluations should be integrated to ensure better understanding of the illness and the child's overall quality of life. It helps establish a therapeutic alliance with the child and family and provides an opportunity for the parent or family to reflect upon and work through their difficulties. ${ }^{38)}$ Psychosocial issues reported by the child and parents, or elicited by the clinician, help determine the key areas to be addressed, and the information obtained must be shared across professionals involved in caring for the child and family. ${ }^{38,39)}$ During an evaluation, if problems such as anxiety, withdrawn behavior, low self-esteem, school refusal, attention deficit, poor scholastic performance, or poor treatment adherence are perceived or reported, the primary physician can refer the child to a mental health professional or a medical social worker for further 
Table 1. Summary of psychosocial problems of children with CKD and their families

\begin{tabular}{|c|c|c|}
\hline Study & Sample & Measures \\
\hline \multicolumn{3}{|l|}{ Children with CKD } \\
\hline $\begin{array}{l}\text { Fukunishi and Honda }{ }^{20)} \\
\text { (1995) }\end{array}$ & $\begin{array}{l}65 \text { (35 kidney transplant } \\
\text { and } 30 \text { CAPD); mean age: } \\
9.9 \text { years (transplant } \\
\text { group), } 9.7 \text { years (CAPD) }\end{array}$ & $\begin{array}{l}\text { Diagnostic interviews for } \\
\text { children and adolescents }\end{array}$ \\
\hline $\begin{array}{l}\text { Fielding and } \\
\text { Brownbridge }^{21)}(1999)\end{array}$ & $\begin{array}{l}\text { 60; less than } 22 \text { years of } \\
\text { age }\end{array}$ & $\begin{array}{l}\text { Measure of the health status } \\
\text { of the sick child, CDI, STAI- } \\
\text { CH }\end{array}$ \\
\hline Madden et al. ${ }^{22)}$ (2003) & $16 ; 1.6-12.1$ years & GMDS, WISC-III, SDQ \\
\hline Bakr et al. $^{23)}(2007)$ & 38; 9-15 years & SCICA \\
\hline Duquette et al. ${ }^{24)}$ (2007) & 30; 6-18 years. & WASI, WIAT-II \\
\hline Gerson et al. ${ }^{25)}$ (2010) & 402; 2-16 years. & PedsQL 4.0 \\
\hline Lande et al. ${ }^{26)}$ (2011) & $383 ; 6-17$ years & $\begin{array}{l}\text { WASI, WIAT-II-A, CPT-II, } \\
\text { BRIEF }\end{array}$ \\
\hline \multicolumn{3}{|l|}{ Parents } \\
\hline $\begin{array}{l}\text { Wiedebusch et al. }{ }^{27)} \\
(2010)\end{array}$ & $\begin{array}{l}195 \text { Parents of children } \\
\text { suffering from the renal } \\
\text { disease }\end{array}$ & IFS, SOEBEK, FKV, ULQIE \\
\hline
\end{tabular}

Tong et al. ${ }^{28)}$ (2010) Parent of 20 children with In-depth interviews CKD

Kili -Pstrusi ska et al. ${ }^{29)} 388$ Parent-proxies of Questionnaire referring to (2014) children with CKD. changes in the family after diagnosing the child with CKD

Geense et al. ${ }^{30)}$ (2017) 20 Families of children with Focus group interviews CKD

Academic problems and nonacademic problems (missing school, absenteeism from school events such as picnic, excursion, and relationship with peers) were highest in the CAPD group, followed by transplant children.

Children who suffered more significant functional impairment due to their illness were likely to show more behavioral disturbance.

The majority of the children undergoing long-term peritoneal dialysis had IQ scores within the average to low average range. There were problems in the conduct, peer relationships, and hyperactivity domain.

The prevalence rate of psychiatric disorders in children with kidney failure was 52.6\%. Adjustment disorders were more common. Anxiety and elimination disorders were reported.

Children with CKD had more absenteeism and grade retention. Lower scores on $I Q$ tests and math reasoning and word reading. Renal function was a significant predictor of academic scores.

The health-related quality of life (HRQoL) was lower in children with CKD. They had significantly lower physical, school, emotional, and social domain scores.

Children with CKD had poorer scores on visuospatial and planning tasks as well as overall scores on WASI.

Parents of children undergoing dialysis experienced more limitations in the quality of life than children living with a kidney graft or undergoing conservative treatment. Mothers had lower HRQoL. The most frequent coping strategies used by parents were improving partnership, support, and focusing on the child.

Parents had difficulty accepting the diagnosis and were traumatized watching their child undergo invasive medical procedures. They depended on health care providers for support and learned from other parents of CKD children.

The child's illness changes the social connections of parents - they had fewer social interactions. Half the parents have never had any contact with the social workers.

Parents expressed the need to have reported needing more information on about their child's disease, medication-related information, and diet plan. They also needed information on how to balance work and life and practical support on child's medical care, support in transport, financial management, and their child at school.

Nicholas $^{31)}$ (2017) 22 Fathers of children with Semistructured interviews

Most fathers identified themselves as their child's coprimary caregiver, especially with giving medication, transport to and fro from the hospital. They felt a loss of personal control and emotional isolation.

\section{Siblings}

Batte et al. ${ }^{32)}(2005) \quad 15$ Siblings of children SCAS undergoing chronic renal failure treatment.

There were no indicators of clinically significant anxiety. However, siblings had concerns about their health worried about changes in the family routine, felt more protective towards their chronically ill siblings and needed to be more grown-up.

Velasco et al. ${ }^{33)}$ (2020) 136 Siblings: 65 siblings of KIDSCREEN-52.

The healthy siblings of kidney transplant patients had a lower subjective perception of physical well-being and financial resources. of LT patients, 36 siblings of CRDs.

Agerskov et al. $^{34)}$ (2020)

Siblings and parents of Semistructured interviews. children with ESRD

Parents: 7 Siblings: 5

The healthy siblings monitored, worried about, and felt for their sick sibling; they expressed annoyance when they could not share experiences. Siblings needed support when the ill child was hospitalized.

CKD, chronic kidney disease; CAPD, continuous ambulatory peritoneal dialysis; CDI, Children's Depression Inventory; STAl-CH, state-trait anxiety inventory for children; GMDS, Griffiths Mental Development Scales for children; WISC-III, Wechsler Intelligence Scale for children third edition; SDQ, strengths and difficulties questionnaire; IQ, intelligence quotient; SCICA, semistructured clinical interview for children and adolescents; WASI, Wechsler Abbreviated Scale of Intelligence; WIAT-II, Wechsler Individual Achievement Test-second edition; PedsQL 4.0, Pediatric Inventory of Quality of Life Core Scales; WIAT-II-A, Wechsler Individual Achievement Test-II-abbreviated; CPT-II, Conners' Continuous Performance Test-II; BRIEF, behavior rating inventory of executive functions; IFS, impact on family scale; SOEBEK, social orientations of parents of handicapped children questionnaire; FKV, freiburg questionnaire of coping with illness; ULQIE, UIm Quality of Life Inventory for Parents; SCAS, Spence Children's Anxiety Scale; KT, kidney transplant; CRD, chronic renal disease; ESRD, end stage renal disease. 


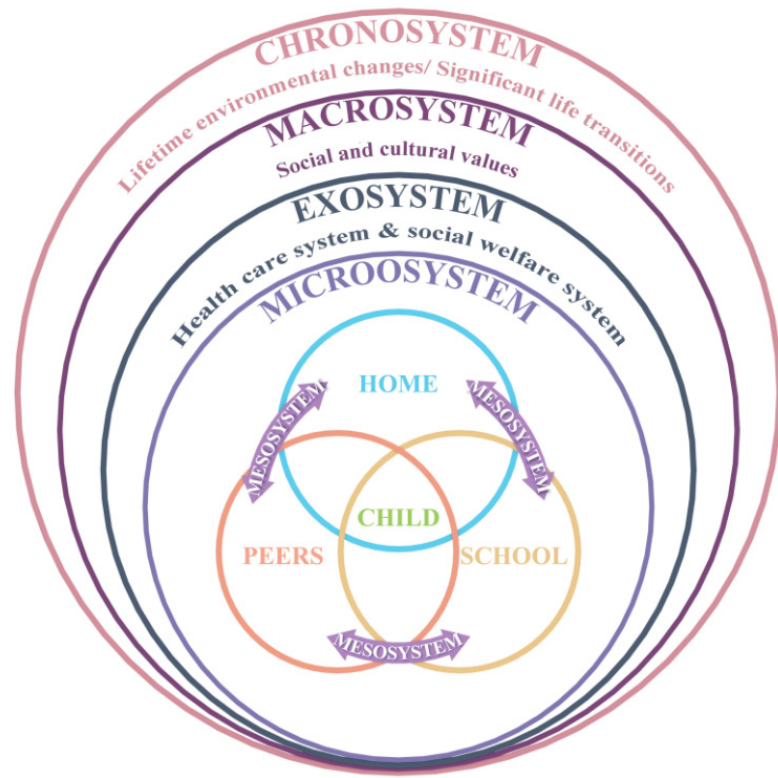

Fig. 1. Bronfenbrenner's ecological model. evaluation. Thus, it ensures early identification and intervention, which lead to better outcomes. Clinicians must also pay attention to the well-being of the siblings, as they are likely to be at risk of adjustment problems. In addition, acknowledging the burden and providing emotional support to the parents or caregivers will help reduce stress.

Some commonly used tools for assessing psychosocial issues and quality of life of children and their parents are provided in Table 2. ${ }^{40-51)}$

\section{Psychosocial management}

Interventions with children are based on various frameworks, such as cognitive-behavioral, art, storytelling, workbooks, games, music, and play, which decrease distress, anxiety, and pain and enhance adjustment. ${ }^{52-56}$ Furthermore, a child's age, developmental level, and cognitive ability should be considered in planning interventions to allow their families to understand

Table 2. Tools for assessing psychosocial issues and quality of life of children and their parents/caregivers

\begin{tabular}{|c|c|c|c|c|}
\hline Tools & Purpose/primary use & $\begin{array}{l}\text { No. of items and } \\
\text { administration time }\end{array}$ & Target population & Strengths and limitations \\
\hline $\begin{array}{l}\text { CBCL/6-18 } \\
\text { YSR/11-18, } \\
\text { and TRF/6- } \\
18)^{40)}\end{array}$ & $\begin{array}{l}\text { It measures internalizing } \\
\text { behavior problems, exter- } \\
\text { nalizing behavior pro- } \\
\text { blems and social compe- } \\
\text { tence in children and } \\
\text { adolescence based on the } \\
\text { preceding } 6 \text { months. }\end{array}$ & $\begin{array}{l}113 \text { Behavioral items, scored as (0) } \\
\text { not true, (1) somewhat true, ( } 2) \\
\text { very true or often true. } \\
15 \text { to } 20 \text { minutes }\end{array}$ & $\begin{array}{l}\text { CBCL/6-18 parents } \\
\text { YSR/11-18 youths TRF/6-18 } \\
\text { teachers familiar to the child }\end{array}$ & $\begin{array}{l}\text { Strengths: Multiple CBCL information can } \\
\text { be collected on the same child. } \\
\text { It is a reliable and valid measure used for } \\
\text { both clinical interventions and research } \\
\text { purposes. } \\
\text { Translated in other languages. } \\
\text { Limitations: It takes a long time to fill the } \\
\text { form. } \\
\text { Scoring is complex. }\end{array}$ \\
\hline $\mathrm{SDQ}^{41)}$ & $\begin{array}{l}\text { It screens children's emo- } \\
\text { tional problems, conduct } \\
\text { disorder, hyperactivity, } \\
\text { peer problems, and pro- } \\
\text { social behaviors over the } \\
\text { last } 6 \text { months. }\end{array}$ & $\begin{array}{l}25 \text { Items, scored as } 0 \text { (not true). } 1 \\
\text { (sometimes true), } 2 \text { (certainly } \\
\text { true). } \\
5 \text { Minutes }\end{array}$ & $\begin{array}{l}\text { Children between ages } 4 \text { to } 17 \\
\text { years; } \\
\text { parent, teacher, and self-report } \\
\text { versions are available }\end{array}$ & $\begin{array}{l}\text { Strengths: reliable and valid measure. } \\
\text { It can be used for both clinical interven- } \\
\text { tions and research purposes. } \\
\text { Easy to administer. } \\
\text { Translated in other languages. } \\
\text { Limitation: children below } 11 \text { years cannot } \\
\text { self-report. }\end{array}$ \\
\hline $\mathrm{RSE}^{42)}$ & $\begin{array}{l}\text { It measures global self- } \\
\text { esteem }\end{array}$ & $\begin{array}{l}10 \text { Items rated on a 4-point scale } \\
\text { as strongly agree, agree, dis- } \\
\text { agree, and strongly disagree. } \\
5 \text { Minutes }\end{array}$ & Children above 12 years & $\begin{array}{l}\text { Strengths: There is considerable evidence } \\
\text { of its reliability and validity. } \\
\text { Translated in other languages. } \\
\text { Quick and easy to administer. } \\
\text { Limitation: Validity not established for } \\
\text { children below } 12 \text { years of age. }\end{array}$ \\
\hline CFSEI- ${ }^{43)}$ & $\begin{array}{l}\text { It is a self-report inventory } \\
\text { to identify children who } \\
\text { may require psychological } \\
\text { evaluation and interven- } \\
\text { tion. It is also applicable in } \\
\text { research studies. }\end{array}$ & $\begin{array}{l}\text { Primary form- } 29 \text { items, Interme- } \\
\text { diate form- } 64 \text { items, Adolescent } \\
\text { form- } 67 \text { items. } \\
\text { The responses are in yes or no } \\
\text { format. } \\
1015 \text { Minutes }\end{array}$ & $\begin{array}{l}\text { Ages between } 6-18.11 \text { years. } \\
\text { Primary form for } 6 \text { to } 8 \text { years of } \\
\text { age } \\
\text { Intermediate form for } 9 \text { to } 12 \\
\text { years of age } \\
\text { Adolescent form for } 13 \text { to } 18 \\
\text { years of age. }\end{array}$ & $\begin{array}{l}\text { Strengths: It is a culture fair test that has } \\
\text { good reliability and validity. } \\
\text { Limitations: Sometimes responses may } \\
\text { not reflect their actual emotional state, } \\
\text { and there are chances of giving socially } \\
\text { desirable answers. }\end{array}$ \\
\hline $\mathrm{CDI}-2^{44)}$ & $\begin{array}{l}\text { It assesses the cognitive, } \\
\text { affective, and behavioral } \\
\text { signs of depression. }\end{array}$ & $\begin{array}{l}\text { CDI 2: Self report has } 28 \text { items and } \\
\text { CDI 2: Self-report short version has } \\
12 \text { items. The responses are } \\
\text { marked as } 0 \text { (absence of } \\
\text { symptoms), } 1 \text { (mild symptom), } 2 \\
\text { (definite symptom). } \\
\text { CDI 2: Teacher has } 12 \text { items, and } \\
\text { CDI 2: parent has } 17 \text { items. The } \\
\text { responses are marked as } 0 \text { (not } \\
\text { at all), } 1 \text { (sometimes), } 2 \text { (often), } 3 \\
\text { (most of the time). } \\
\text { 5-15 Minutes }\end{array}$ & $\begin{array}{l}\text { Parent, teacher, and self-report } \\
\text { ( } 7-17 \text { years) are available }\end{array}$ & $\begin{array}{l}\text { Strengths: Reliable and valid tool and can } \\
\text { be used in settings such as schools and } \\
\text { clinics. } \\
\text { Translated in other languages. } \\
\text { Limitations: test results must be corro- } \\
\text { borated with other findings such as } \\
\text { clinical interview and must be confirmed } \\
\text { by a qualified clinician. }\end{array}$ \\
\hline
\end{tabular}


Table 2. Tools for assessing psychosocial issues and quality of life of children and their parents/caregivers (continued)

\begin{tabular}{|c|c|c|c|c|}
\hline Tools & Purpose/primary use & $\begin{array}{l}\text { No. of items and } \\
\text { administration time }\end{array}$ & Target population & Strengths and limitations \\
\hline SCARED $^{45)}$ & $\begin{array}{l}\text { It screens for childhood anxiety } \\
\text { disorder and assesses panic/ } \\
\text { somatic, separation anxiety, } \\
\text { generalized anxiety, and school } \\
\text { phobia. }\end{array}$ & $\begin{array}{l}41 \text { Items rated on a 3-point scale } \\
0 \text { (not true) to } 2 \text { (very true) }\end{array}$ & $\begin{array}{l}\text { Children between 8-18 years. } \\
\text { Both child and parent versions } \\
\text { are available. }\end{array}$ & $\begin{array}{l}\text { Strengths: It is a valid measure with } \\
\text { good and sensitive to change in } \\
\text { short interventions. } \\
\text { Translated in other languages. } \\
\text { Limitations: It should be used by a } \\
\text { trained clinician } \\
\text { Insufficient evidence of test-retest } \\
\text { reliability over short periods of } \\
\text { time. }\end{array}$ \\
\hline STAI-CH ${ }^{46)}$ & $\begin{array}{l}\text { It evaluates the current state of } \\
\text { anxiety and also measures the } \\
\text { stable aspects of anxiety. }\end{array}$ & $\begin{array}{l}40 \text { Items and responses are rated } \\
\text { on a 3-point scale. } \\
20 \text { Minutes }\end{array}$ & $\begin{array}{l}\text { It is applicable for children between } \\
9-12 \text { years. Both parent and child } \\
\text { versions are available. }\end{array}$ & $\begin{array}{l}\text { Strengths: It is a widely used mea- } \\
\text { sure of anxiety } \\
\text { Translated in other languages. } \\
\text { Limitations: The ability to detect } \\
\text { change in trait anxiety is less } \\
\text { responsive as compared to state } \\
\text { anxiety. }\end{array}$ \\
\hline PedsQL 4.047) & $\begin{array}{l}\text { It can be used across pediatric } \\
\text { populations with chronic and } \\
\text { acute health conditions, com- } \\
\text { munity and school populations. } \\
\text { Measures the physical, emo- } \\
\text { tional, social, and school do- } \\
\text { mains. }\end{array}$ & $\begin{array}{l}23 \text { Items; Parent report and child } \\
\text { report format: } 5 \text {-point res- } \\
\text { ponse scale (0 to 4). } \\
\text { Young child self-report format } \\
\text { (ages 5-7): } 3 \text {-point scale. } \\
5 \text { Minutes }\end{array}$ & $\begin{array}{l}\text { It has versions for toddlers (2-4), } \\
\text { young children (5-7), children } \\
(8-12), \text { and teens (13-18). Child } \\
\text { rated version and parent-rated } \\
\text { version are available. }\end{array}$ & $\begin{array}{l}\text { Strengths: Quick completion and } \\
\text { easy to score. } \\
\text { It has good psychometric properties. } \\
\text { Translated in other languages. } \\
\text { Limitations: Charges applicable for } \\
\text { funded research which can be } \\
\text { expensive. }\end{array}$ \\
\hline $\begin{array}{l}\text { PedsQL ESRD } \\
\text { Module } \\
3.0^{48)}\end{array}$ & $\begin{array}{l}\text { It measures end-stage renal dis- } \\
\text { ease-specific health-related } \\
\text { quality of life-general fatigue } \\
\text { about my kidney disease, treat- } \\
\text { ment problems, family and peer } \\
\text { interaction, worry, perceived } \\
\text { physical appearance, and com- } \\
\text { munication. }\end{array}$ & $\begin{array}{l}34 \text { Items and } 7 \text { subscales. } \\
\text { Parent report and child report } \\
\text { format: } 5 \text {-point response scale } \\
\text { (0 to 4). } \\
\text { Young child self-report format } \\
\text { (ages 5-7): 3-point scale. } \\
\text { 10 Minutes }\end{array}$ & $\begin{array}{l}\text { It has versions for toddlers }(2-4) \text {, } \\
\text { young children }(5-7) \text {, children } \\
(8-12) \text {, and teens }(13-18) \text {. Child } \\
\text { rated version and parent-rated } \\
\text { version are available. }\end{array}$ & $\begin{array}{l}\text { Strengths: It has good psycho- } \\
\text { metric properties. } \\
\text { Translated in other languages. } \\
\text { Limitations: Charges applicable for } \\
\text { funded research which can be } \\
\text { expensive. }\end{array}$ \\
\hline $\mathrm{GHQ}-12^{49)}$ & $\begin{array}{l}\text { Designed to measure the current } \\
\text { mental health, GHQ was initially } \\
\text { developed as a } 60 \text {-item instru- } \\
\text { ment, but a range of shortened } \\
\text { versions } 12,20,30 \text { are avail- } \\
\text { able. }\end{array}$ & $\begin{array}{l}12 \text { Statements, rated on a } 4^{-} \\
\text {point scale (less than usual, } \\
\text { more than usual, rather more } \\
\text { than usual, and much more } \\
\text { than usual). } \\
5 \text { Minutes }\end{array}$ & Adolescents, parents & $\begin{array}{l}\text { Strengths: The GHQ-12 is brief, } \\
\text { simple, easy to complete, and } \\
\text { scored. } \\
\text { Its application in research settings } \\
\text { as a screening tool is well docu- } \\
\text { mented. } \\
\text { Translated in other languages. } \\
\text { Limitations: Possibility of response } \\
\text { bias on negatively stated items. }\end{array}$ \\
\hline $\mathrm{ZBI}^{50)}$ & $\begin{array}{l}\text { It is designed to reflect the care- } \\
\text { giver's stresses. }\end{array}$ & $\begin{array}{l}22 \text { Items rated on a 5-point scale } \\
\text { from } 0 \text { (never) to } 4 \text { (nearly } \\
\text { always). } \\
5 \text { minutes }\end{array}$ & Caregivers' self-report & $\begin{array}{l}\text { Strengths: It has been widely used } \\
\text { in clinical practice and research. } \\
\text { Translated in other languages. } \\
\text { Limitations: The self-checklist } \\
\text { format can be limiting. }\end{array}$ \\
\hline $\mathrm{FES}^{51)}$ & $\begin{array}{l}\text { It examines the family members' } \\
\text { current family as they perceive } \\
\text { it, the type of family they prefer, } \\
\text { and their expectations of what a } \\
\text { family will be like. The FES can be } \\
\text { measured in } 3 \text { ways Real (form } \\
\text { R), Ideal form I) and Expected } \\
\text { (form E). The FES is composed } \\
\text { of } 10 \text { subscales measuring } 3 \\
\text { dimensions namely family } \\
\text { relationship, personal growth, } \\
\text { and system maintenance and } \\
\text { change. } \\
\text { It is mainly used in clinical settings } \\
\text { to facilitate family therapy. }\end{array}$ & $\begin{array}{l}90 \text { True or false items. } \\
15-20 \text { Minutes }\end{array}$ & Children 11 years and older & $\begin{array}{l}\text { Strengths: Widely used tool } \\
\text { Translated in other languages. } \\
\text { Limitations: Low internal consis- } \\
\text { tency for } 5 \text { subscales. }\end{array}$ \\
\hline
\end{tabular}

CBCL/6-18, child behavior checklist; YSR/11-18, youth self-report; TRF/6-18, teacher's rating form; SDQ, strengths and difficulties questionnaire; RSE, Rosenberg Self-esteem Scale; CFSEI-3, culture free self-esteem inventory 3rd edition; CDI-2, Children's Depression Inventory-2nd edition; SCARED, screen for child anxiety related emotional disorders; STAI-CH, state-trait anxiety inventory for children; PedsQL 4.0, Peds Quality of Life Questionnaire; PedsQL ESRD Module 3.0, ESRDspecific module; GHQ-12, general health questionnaire; ZBI, Zarit burden interview; FES, family environment scale. 


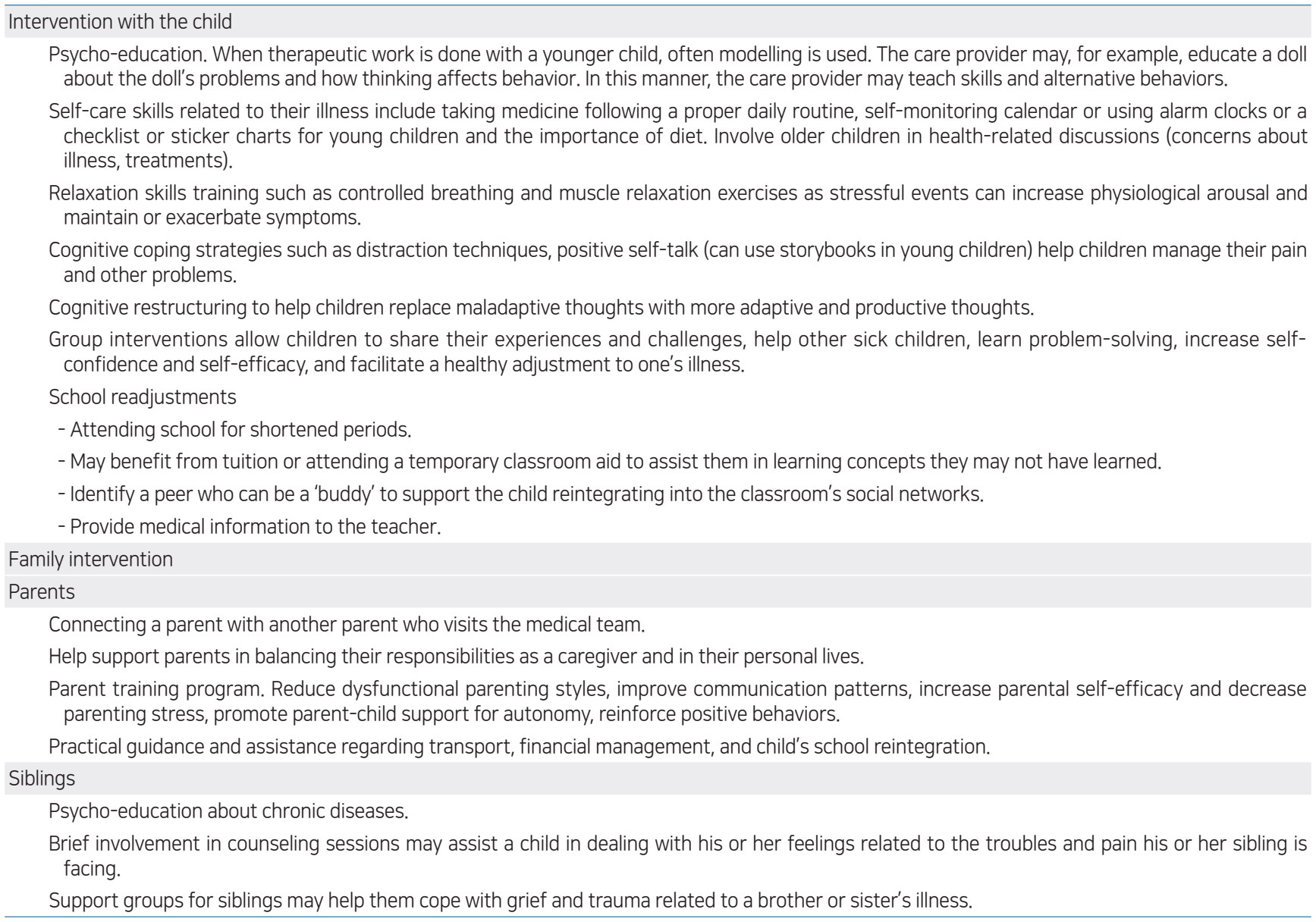

and prepare. VanLeeuwen and Mathews highlighted the need for psychological preparation, mental health consultation, therapeutic intervention, and continuous counseling to prevent unnecessary psychological stress in a pediatric dialysis program. 57) Warady and Chadha ${ }^{58)}$ reported that therapeutic camps organized for children with kidney failure were successful, indicating reduced depression, improved self-esteem and selfconfidence, and overall promotion of emotional maturity. Meade et al. explored the development and implementation of a self-management program designed to address noncompliance in adolescents with kidney failure on renal replacement therapy. ${ }^{59)}$ They found that the program effectively created a supportive environment for patients and their parents and addressed healthrelated concerns. Hashim et al. ${ }^{60)}$ described a dialectical behavior therapy adaptation to improve adherence in adolescent patients with kidney failure. Families also require intervention to help them cope with the stress while providing care. Some aspects of psychological management are shown in Table 3.

\section{Conclusion}

Despite medical advances, CKD can take a toll on a child's social and emotional functioning. Primary care physicians must become proficient at recognizing psychosocial issues, assume a more supportive role, and collaborate with families to address these issues. Awareness and understanding of the child's condition will improve medication adherence. In addition, screening and monitoring psychological status and referrals for mental health services will enable comprehensive treatment. The best care for children with CKD in addition to medication should involve identifying and managing psychosocial factors, which will facilitate a successful transition to adult life.

\section{Footnotes}

Conflicts of interest: No potential conflict of interest relevant to this article was reported.

Funding: The authors received no financial support for the research, authorship, and publication of this article

ORCID:

Vijaya Raman @ https://orcid.org/0000-0003-0578-5276 


\section{References}

1. Aoto H, Nakatani H, Kanayama S, Okada SI, Fukada M, Hanaki K. Qualitative analysis of the psychosocial adaptation process in children with chronic kidney disease: toward effective support during transition from childhood to adulthood. Yonago Acta Med 2018;61:166-74.

2. Watson AR. Psychosocial support for children and families requiring renal replacement therapy. Pediatr Nephrol 2014;29:1169-74.

3. Lavigne JV, Faier-Routman J. Psychological adjustment to pediatric physical disorders: a meta-analytic review. J Pediatr Psychol 1992;17:13357.

4. Pinquart M, Shen Y. Behavior problems in children and adolescents with chronic physical illness: a meta-analysis. J Pediatr Psychol 2011;36:100316.

5. Levey AS, Eckardt KU, Dorman NM, Christiansen SL, Hoorn EJ, Ingelfinger JR, et al. Nomenclature for kidney function and disease: report of a Kidney Disease: Improving Global Outcomes (KDIGO) Consensus Conference. Kidney Int 2020;97:1117-29.

6. Warady BA, Chadha V. Chronic kidney disease in children: the global perspective. Pediatr Nephrol 2007;22:1999-2009.

7. Harambat J, van Stralen KJ, Kim JJ, Tizard EJ. Epidemiology of chronic kidney disease in children. Pediatr Nephrol 2012;27:363-73. Erratum in: Pediatr Nephrol 2012;27:507.

8. Vivante A, Hildebrandt F. Exploring the genetic basis of early-onset chronic kidney disease. Nat Rev Nephrol 2016;12:133-46.

9. Becherucci F, Roperto RM, Materassi M, Romagnani P. Chronic kidney disease in children. Clin Kidney J 2016;9:583-91.

10. McDonald SP, Craig JC; Australian and New Zealand Paediatric Nephrology Association. Long-term survival of children with end-stage renal disease. NEngl J Med 2004;350:2654-62.

11. Mitsnefes MM, Laskin BL, Dahhou M, Zhang X, Foster BJ. Mortality risk among children initially treated with dialysis for end-stage kidney disease, 1990-2010. JAMA 2013;309:1921-9.

12. Greenbaum LA, Warady BA, Furth SL. Current advances in chronic kidney disease in children: growth, cardiovascular, and neurocognitive risk factors. Semin Nephrol 2009;29:425-34.

13. Groothoff JW, Grootenhuis MA, Offringa M, Stronks K, Hutten GJ, Heymans HS. Social consequences in adult life of end-stage renal disease in childhood. J Pediatr 2005;146:512-7.

14. Lewis H, Marks SD. Differences between paediatric and adult presentation of ESKD in attainment of adult social goals. Pediatr Nephrol 2014; 29:2379-85.

15. Manti P, Giannakopoulos G, Giouroukou E, Georgaki-Angelaki H, Stefanidis CJ, Mitsioni A, et al. Psychosocial and cognitive function in children with nephrotic syndrome: association with disease and treatment variables. Biopsychosoc Med 2013;7:10.

16. Bignall ON 2nd, Goldstein SL. Childhood CKD affects the entire family. Am J Kidney Dis 2015;65:367-8.

17. Tong A, Lowe A, Sainsbury P, Craig JC. Experiences of parents who have children with chronic kidney disease: a systematic review of qualitative studies. Pediatrics 2008;121:349-60.

18. Alderfer MA, Labay LE, Kazak AE. Brief report: does posttraumatic stress apply to siblings of childhood cancer survivors? J Pediatr Psychol 2003;28:281-6.

19. Redshaw S, Wilson V. Sibling involvement in childhood chronic heart disease through a bead program. J Child Health Care 2012;16:53-61.

20. Fukunishi I, Honda M. School adjustment of children with end-stage renal disease. Pediatr Nephrol 1995;9:553-7.

21. Fielding D, Brownbridge G. Factors related to psychosocial adjustment in children with end-stage renal failure. Pediatr Nephrol 1999;13:766-70.

22. Madden SJ, Ledermann SE, Guerrero-Blanco M, Bruce M, Trompeter RS. Cognitive and psychosocial outcome of infants dialysed in infancy. Child Care Health Dev 2003;29:55-61.

23. Bakr A, Amr M, Sarhan A, Hammad A, Ragab M, El-Refaey A, et al. Psychiatric disorders in children with chronic renal failure. Pediatr Nephrol 2007;22:128-31.
24. Duquette PJ, Hooper SR, Wetherington CE, Icard PF, Gipson DS. Brief report: intellectual and academic functioning in pediatric chronic kidney disease. J Pediatr Psychol 2007;32:1011-7.

25. Gerson AC, Wentz A, Abraham AG, Mendley SR, Hooper SR, Butler RW, et al. Health-related quality of life of children with mild to moderate chronic kidney disease. Pediatrics 2010;125:e349-57.

26. Lande MB, Gerson AC, Hooper SR, Cox C, Matheson M, Mendley $\mathrm{SR}$, et al. Casual blood pressure and neurocognitive function in children with chronic kidney disease: a report of the children with chronic kidney disease cohort study. Clin J Am Soc Nephrol 2011;6:1831-7.

27. Wiedebusch S, Konrad M, Foppe H, Reichwald-Klugger E, Schaefer F, Schreiber V, et al. Health-related quality of life, psychosocial strains, and coping in parents of children with chronic renal failure. Pediatr Nephrol 2010;25:1477-85.

28. Tong A, Lowe A, Sainsbury P, Craig JC. Parental perspectives on caring for a child with chronic kidney disease: an in-depth interview study. Child Care Health Dev 2010;36:549-57.

29. Kiliś-Pstrusińska K, Medyńska A, Adamczyk P, Bałasz-Chmielewska I, Grenda R, Kluska-Jóźwiak A, et al. Disease-related social situation in family of children with chronic kidney disease--parents' assessment. A multicentre study. Ann Agric Environ Med 2014;21:876-81.

30. Geense WW, van Gaal BGI, Knoll JL, Cornelissen EAM, van Achterberg T. The support needs of parents having a child with a chronic kidney disease: a focus group study. Child Care Health Dev 2017;43:831-8.

31. Nicholas DB. Examining the roles and experiences of fathers of children with chronic kidney disease. Glob Qual Nurs Res 2017;4:233339361 7705035.

32. Batte S, Watson AR, Amess K. The effects of chronic renal failure on siblings. Pediatr Nephrol 2006;21:246-50.

33. Velasco J, Ferraris V, Eymann A, Coccia PA, Ghezzi LR, Sánchez MC, et al. Quality of life among siblings of patients with chronic conditions. Arch Argent Pediatr 2020;118:252-7.

34. Agerskov H, Thiesson HC, Pedersen BD. The significance of relationships and dynamics in families with a child with end-stage kidney disease: a qualitative study. J Clin Nurs 2020;29:987-95.

35. Drotar D. Psychological interventions for children with chronic physical illness and their families. In: Russ SW, Ollendick TH, editors. Handbook of psychotherapies with children and families. Boston: Springer, 1999: 447-61.

36. Bronfenbrenner U. The ecology of human development: experiments by nature and design. Cambridge (MA): Harvard University Press, 1979.

37. Kazak A, Nachman G. Family research on childhood chronic illness: pediatric oncology as an example. J Family Psychol 1991;4:462-83.

38. Srinath S, Jacob P, Sharma E, Gautam A. Clinical practice guidelines for assessment of children and adolescents. Indian J Psychiatry 2019;61:15875 .

39. Bhide A, Chakraborty K. General principles for psychotherapeutic interventions in children and adolescents. Indian J Psychiatry 2020;62: S299-318.

40. Achenbach TM, Rescorla LA. Manual for the ASEBA school-age forms \& profiles: an integrated system of multi-informant assessment. Burlington (VT): University of Vermont, Research Center for Children, Youth \& Families, 2001.

41. Goodman R. The Strengths and Difficulties Questionnaire: a research note. J Child Psychol Psychiatry 1997;38:581-6.

42. Rosenberg M. Society and the adolescent self-image. Princeton (NJ): Princeton University Press, 1965.

43. Battle J. Culture-free self-esteem inventories: examiner's manual. 3rd ed. Austin (TX): Pro-Ed, 2002.

44. Kovacs M. Children's depression inventory 2nd edition (CDI 2): technical manual. North Tonawanda (NY): Multi-Health Systems, 2011.

45. Birmaher B, Brent DA, Chiappetta L, Bridge J, Monga S, Baugher M. Psychometric properties of the Screen for Child Anxiety Related Emotional Disorders (SCARED): a replication study. J Am Acad Child Adolesc Psychiatry 1999;38:1230-6.

46. Speilberger CD. Manual for the state-trait anxiety inventory for children. Palo Alto (CA): Consulting Psychologists' Press, 1973. 
47. Varni JW, Burwinkle TM, Seid M, Skarr D. The PedsQL 4.0 as a pediatric population health measure: feasibility, reliability, and validity. Ambul Pediatr 2003;3:329-41.

48. Goldstein SL, Graham N, Burwinkle T, Warady B, Farrah R, Varni JW. Health-related quality of life in pediatric patients with ESRD. Pediatr Nephrol 2006;21:846-50.

49. Goldberg $\mathrm{D}$. Use of the general health questionnaire in clinical work. $\mathrm{Br}$ Med J (Clin Res Ed) 1986;293:1188-9.

50. Zarit SH, Zarit JM. The memory and behavior problems checklist: 1987R and the burden interview (technical report). University Park (PA): Pennsylvania State University, 1987.

51. Moos RH, Moos BS. Family environment scale manual. 3rd ed. Palo Alto (CA): Consulting Psychologists Press, 1994.

52. Barlow JH, Ellard DR. Psycho-educational interventions for children with chronic disease, parents and siblings: an overview of the research evidence base. Child Care Health Dev 2004;30:637-45.

53. Pielech M, Sieberg CB, Simons LE. Connecting parents of children with chronic pain through art therapy. Clin Pract Pediatr Psychol 2013;1:21426.

54. Freeman M. Therapeutic use of storytelling for older children who are critically ill. Child Health Care 1991;20:208-15.

55. Treurnicht Naylor K, Kingsnorth S, Lamont A, McKeever P, Macarthur C. The effectiveness of music in pediatric healthcare: a systematic review of randomized controlled trials. Evid Based Complement Alternat Med 2011;2011:464759.

56. Gariépy N, Howe N. The therapeutic power of play: examining the play of young children with leukaemia. Child Care Health Dev 2003;29:52337.

57. VanLeeuwen JJ, Matthews DE. Comprehensive mental health care in a pediatric dialysis-transplantation program. Can Med Assoc J 1975;113:959-62.

58. Warady BA. Therapeutic camping for children with end-stage renal disease. Pediatr Nephrol 1994;8:387-90.

59. Meade MA, Creer TL, Mahan JD. A self-management program for adolescents and children with renal transplantation. J Clin Psycho Med Settings 2003;10:165-71.

60. Hashim B, Vadnais M, Miller A. Improving adherence in adolescent chronic kidney disease: a dialectical behavior therapy (DBT) feasibility trial. Clin Pract Pediatr Psychol 2013;1:369-79.

How to cite this article: Aier A, Pais P, Raman V. Psychosocial aspects of children with chronic kidney disease and their families. Clin Exp Pediatr 2022;65:222-9. https://doi.org/10.3345/cep. 2021.01004 